\title{
Hubungan Lingkungan Sosial dan Media Massa dengan Kejadian Menarche Dini pada Anak Sekolah Siswi Kelas V dan VI di SDN 205 Kota Baru Kota Jambi Tahun 2018
}

\author{
Hasyim Kadri ${ }^{1}$, Salvita Fitrianti ${ }^{2}$ \\ 1,2Sekolah Tinggi Ilmu Kesehatan Baiturrahim Jambi \\ Correspondence email: h451mkadri87@yahoo.com
}

\begin{abstract}
Abstrak. Menarche adalah permulaan menstruasi pada seorang gadis pada masa pubertas, yang biasanya muncul pada usia 11 14 tahun. Menarche merupakan pertanda adanya suatu perubahan status sosial dari anak-anak ke dewasa, remaja putri yang mempunyai kecenderungan neurotis dalam usia pubertas banyak mengalami konflik batin dengan datangnya menstruasi pertama yang dapat menimbulkan tingkah laku patologis (Sukarni k ,dkk 2013), Terjadinya Menarche pada setiap wanita tidaklah sama karena ada beberapa faktor yang mempengaruhinya, antara lain faktor sosial-ekonomi, keturunan, lingkungan sosial dan juga faktor kesehatan dan status gizi. Remaja putri yang berbadan gemuk biasanya cenderung mengalami Menarche lebih awal dari pada remaja putri yang berbadan kurus (Andira, D. 2010). Tujuan Penelitian Diketahuinya Hubungan Lingkungan Sosial, dan Media Massa dengan kejadian Menarche dini Pada anak sekolah siswi kelas V dan VI SDN 205 Kecamatan Kota Baru Kota Jambi. Desain penelitian ini bersifat kuatitatif dengan metode penelitian survey analitik, dengan mengunakan pendekatan Cross Sectional. Populasi dalam penelitian ini adalah seluruh siswi kelas V dan VI yang Menarche dini di SDN 205 Kota Jambi. Sampel dalam penelitian ini adalah seluruh (Total Sampling) siswi kelas V dan VI yang telah Menarche di SDN 205 Kota Jambi yang berjumlah 45 Responden. Dalam penetian ini dilakukan analisis Univariat, Bivariat. Hasil analisis tersebut didapatkan bahwa ada hubungan lingkungan sosial ( $p$ value 0.000) dan media massa ( $p$ value 0.002). Disarankan agar lebih meningkatkan dalam melakukan konseling mengenai Menarche dini maupun nyeri Menarche kepada siswi serta lebih mengaktifkan kegiatan UKS.
\end{abstract}

Kata Kunci: Lingkungan Sosial dan Media Massa; Menarche dini

\begin{abstract}
Menarche is the beginning of menstruation in a girl during puberty, which usually appears at the age of 11-14 years. Menarche is a sign of a change in the social status of children to adulthood, young women who have the tendency of neurotic in pubertal age many have an inner conflict with the advent of the first menstruation that can cause Pathological behavior (Sukarni $K$, DKK 2013), the occurrence of Menarche in every woman is not the same because there are several factors influencing it, such as socio-economic factors, heredity, social environment and also health factor and nutritional status. Fat-headed young women usually tend to experience Menarche earlier than in the thin-body young women (Andira, D. 2010). Research aims to be knew social environment relations, and mass Media with the event of early Menarche in school students class V and VI SDN 205 kota Baru City of Jambi. The design of this research is an effective method of research with analytic surveys, using the Cross Sectional approach. The population in this study is all students of class V and VI that Menarche early at SDN 205 Kota Jambi. The samples in this study were all (Total Sampling) of class V and VI who had Menarche at SDN 205 Kota Jambi which amounted to 45 respondents. In this insulation conducted analysis of Univariat, Bivariat. he results of the analysis gained that there is a social environment ( $p$ value 0.000 ) and mass media ( $p$ value 0.002). It is recommended to further improve the counseling on early Menarche as well as Menarche pain to the students and more activating UKS activities.
\end{abstract}

Keywords: Social environment and mass media; menarche scratch

\section{PENDAHULUAN}

Masa remaja merupakan salah satu periode dari perkembangan manusia. Masa ini merupakan masa perubahan atau peralihan dari masa kanak-kanak ke masa dewasa yang meliputi perubahan biologik, perubahan psikologik dan perubahan sosial. Menurut World Health Organization (WHO) remaja merupakan individu yang sedang mengalami masa peralihan yang secara berangsur-angsur mencapai kematangan seksual, mengalami perubahan jiwa dari jiwa kanakkanak menjadi dewasa dan mengalami perubahan keadaan ekonomi dan ketergantungan menjadi relatif mandiri (Notoatmodjo, S. 2007).

Kematangan seksual pada remaja pria biasanya terjadi pada usia 10,0-13,5 tahun sedangkan pada remaja putri terjadi pada usia 9,0-15,0 tahun. Bagi anak laki-laki perubahan itu ditandai oleh perkembangan pada organ seksual. seperti mulai tumbuhnya rambut kemaluan, perubahan suara dan juga ejakulasi pertama melalui wet dream atau mimpi basah. Sedangkan pada remaja putri pubertas ditandai dengan menarche (haid pertama), perubahan pada dada (mammae), tumbuhnya rambut kemaluan dan juga pembesaran panggul. Usia remaja putri saat mengalami menarche bervariasi, yaitu antara usia 10-16 tahun tetapi rata-rata pada usia 12,5 tahun.

Usia untuk mencapai fase terjadinya menarche dipengaruhi oleh banyak faktor antara lain faktor suku, genetik, gizi, sosial,ekonomi. Di Inggris usia rata-rata untuk mencapai menarche adalah 13,1 tahun, sedangkan suku Bundi di Papua Nugini menarche dicapai pada usia 18,8 tahun. Anak wanita yang menderita kelainan tertentu selama dalam kandungan mendapatkan menarche pada usia lebih muda dari usia rata-rata. Sebaliknya anak wanita yang menderita cacat mental dan mongolisme akan mendapat menarche pada usia yang lebih lambat. Terjadinya penurunan usia dalam mendapatkan menarche sebagian besar dipengaruhi oleh adanya perbaikan gizi (Proverawati,A dan Misaroh, S. 2009).

Faktor penyebab menarche dini juga datang dari rangsangan audio visual, baik berasal dari percakapan maupun tontonan dari film-film atau internet berlabel dewasa, vulgar atau mengumbar seksualitas. 
Rangsangan dari telinga dan mata tersebut kemudian merangsang sistem reproduksi dan genital untuk lebih cepat matang (Proverawati, A \& Misaroh, S.2009).

Berdasarkan studi pendahuluan pada tanggal 22 Februari 2017 yang diambil pada 20 orang anak di SDN 205/IV, siswi yang menarche pada usia 8 tahun sebanyak 4 orang siswi, pada usia 9 tahun sebanyak 7 orang siswi, pada usia 10 tahun sebanyak 4 orang siswi dan pada usia 11 tahun sebanyak 5 orang siswi. Dari hasil wawancara diketahui rata-rata siswi sering makanan siap saji, jajan pinggir jalan dan menggunakan media massa seperti menonton televisi tanpa didampingi orang tua, sering menggunakan fasilitas internet.

Tujuan penelitian ini untuk Mengetahui Hubungan Lingkungan Sosial dan Media Masa secara simultan dengan kejadian Menarche Dini Pada anak sekolah siswi kelas V dan VI SDN 205 Kecamatan Kota Baru Kota Jambi Tahun 2018.

\section{METODE PENELITIAN}

Desain penelitian ini bersifat kuatitatif dengan metode penelitian survey analitik, dengan mengunakan pendekatan Cross Sectional untuk melihat hubungan antara variabel dependen dan variabel independen (Natoatmodjo, 2010). Penelitian dilakukan pada tanggal 15-19 Mei tahun 2018, dilaksanakan di SDN 205 Kecamatan Kota Baru Kota Jambi. Populasi dalam penelitian ini adalah seluruh siswi kelas $\mathrm{V}$ dan $\mathrm{VI}$ yang menarche dini di SDN 205 Kecamatan Kota Baru Kota Jambi. Jumlah populasi dalam penelitian ini di SDN 205 sebanyak 65 orang siswi. Sampel dalam penelitian ini adalah seluruh siswi kelas $\mathrm{V}$ dan $\mathrm{VI}$ yang telah menarche di SDN 205 Kecamatan Kota Baru Kota Jambi yang berjumlah 45 orang., dengan tehknik pengambilan sampel yaitu Total Sampling.

\section{HASIL DAN PEMBAHASAN}

Untuk mengetahui apakah variabel independen berhubungan dengan variabel dependen, maka dilakukan analisa bivariat dengan menggunakan uji statistik Chi-Square dengan hasil sebagai berikut:

Dari hasil penelitian yang dilakukan pada 45 responden dimana lingkungan sosial dikategorikan menjadi dua yaitu kurang baik dan baik. Kejadian Menarche dini dikatagorikan menjadi dua yaitu normal dan tidak normal dapat dilihat pada Tabel 1 di bawah ini.

Tabel 1. Distribusi Responden Menurut Lingkungan Sosial Terhadap Kejadian Menarchedini pada Siswi Kelas V dan VI di SDN 205 Kota Baru Kota Jambi Tahun 2018

\begin{tabular}{|c|c|c|c|c|c|c|c|}
\hline \multirow{3}{*}{ Lingkungan Sosial } & \multicolumn{4}{|c|}{ UsiaMenarche } & \multicolumn{2}{|c|}{ Jumlah } & \multirow[t]{3}{*}{$\mathrm{p}$-value } \\
\hline & \multicolumn{2}{|c|}{ Tidak Normal } & \multicolumn{2}{|c|}{ Normal } & & & \\
\hline & $\mathrm{n}$ & $\%$ & $\mathrm{n}$ & $\%$ & $\mathrm{~N}$ & $\%$ & \\
\hline Kurang Baik & 15 & 83,3 & 3 & 16,7 & 18 & 100 & 0,000 \\
\hline Baik & 1 & 3,7 & 26 & 96,3 & 27 & 100 & \\
\hline Jumlah & 16 & 35,6 & 29 & 64,4 & 45 & 100 & \\
\hline
\end{tabular}

Berdasarkan Hasil analisis data bivariathubungan antara Menarcheterhadap lingkungan sosial dari 18 responden yang lingkungan sosial kurang baik ada sebanyak 3 orang $(16,7 \%)$ yang normal usia Menarchedan 15 orang $(83,3 \%)$ yang tidak normal usia Menarche atau Menarchedini. Dari 27responden yang Lingkungan sosial baik ada sebanyak 26 orang $(96,3 \%)$ yangnormal usia Menarchedan 1 orang $(3,7 \%)$ yang tidak normal usia Menarche atau Menarche dini. Dari hasil Uji statistik di peroleh $\rho$ value $=0,000$ maka dapat disimpulkan bahwa secara statistik pada alpa 5\% ada hubungan yang signifikan anatara lingkungan sosial terhadap Menarchedini pada anak sekolah siswikelas $\mathrm{V}$ dan VI di SDN 205 Kota Baru Kota Jambi Tahun 2017Dari analisis di dapat OR130,00artinya responden yang Lingkungan sosialnya rendah mempunyai kecendrungan 130,00kali usia Menarchetidak normal atau Menarchedini .

Berdasarkan hasil analisis hubungan antara lingkungan sosial dengan kejadian Menarche dini pada anak sekolah siswi kelas V dan VI SDN205 Kota Jambi Tahun 2018 di peroleh bahwa dari 45 responden dengan lingkungan sosial yang kurang baik dan mengalami kejadian Menarche dini sebanyak 15 responden (83,3\%) dan yang tidak mengalami kejadian Menarche dinisebanyak 3responden(16,7\%). Sedangkan dari 27 responden dengan lingkungan sosial baik yang mengalami kejadian Menarche dinisebanyak 1 responden $(3,7 \%)$ dan yang tidak mengalami kejadian Menarche dinisebanyak 26responden (96,3\%).

Hasil uji statistik Chi-Square didapat nilai $p$ value 0,000 berarti $<\alpha(0,05)$. Hal ini menunjukkan bahwaada hubungan yang signifikan antara lingkungan sosial dengan kejadian Menarche dinipada anak sekolah siswi kelas V dan VI SDN205 Kota Jambi.

Dari hasil analisis di peroleh nilai OR : 130,00 artinya responden dengan lingkungan sosial kurang baik mempunyai peluang $130,00 \mathrm{kali}$ untuk mengalami terjadinya Menarche dini bila dibandingkan responden dengan lingkungan sosial baik.

Menurut Sabarna, (2008) Lingkungan sosial berpengaruh terhadap waktu terjadinya Menarche Salah satunya yaitu lingkungan keluarga. Lingkungan keluarga yang harmonis dan adanya keluarga besar yang baik dapat memperlambat terjadinya Menarche dini sedangkan anak yang tinggal di tengah-tengah keluarga yang tidak harmonis dapat mengakibatkan terjadinya Menarche dini. Beberapa aspek struktur dan fungsi keluarga berpengaruh terhadap kajadian Menarche dini yaitu sebagai berikut :

1) Ketidakhadiran seorang ayah ketika ia masih kecil.

2) Kekerasan seksual pada anak.

Pelecehan seksual pada anak adalah kondisi dimana anak terlibat dalam aktivitas seksual dimana anak sama sekali tidak menyadari dan tidak mampu mengkomunikasikannya atau bahkan tidak tahu arti tindakan yang diterimanya. Semua tindakan yang 
melibatkan anak dalam kesenangan seksual masuk dalam kategori ini:

a) Pelecehan seksual tanpa sentuhan. Termasuk didalamnya jika anak melihat pornografi.

b) Pelecehan seksual dengan sentuhan. Semua tindakan anak menyentuh organ seksual orang dewasa termasuk dalam kategori ini. Atau adanya penetrasi ke dalam vagina anak dengan benda apapun yang tidak mempunyai tujuan medis.

c) Eksploitasi seksual. Meliputi semua tindakan yang menyebabkan anak masuk dalam tujuan prostitusi, atau menggunakan anak sebagai model foto atau film porno

Faktor yang berpengaruh terhadap waktu terjadinya Menarche yaitu faktor lingkungan di mana remaja tersebut berada, seperti lingkungan keluarga, kelompok sebaya atau teman akrab dan sumberinformasi (Bambang, 2004).

Hasil penelitian ini juga sejalan dengan hasil penelitian yang dilakukan olehPenelitian Irma Harahap Tahun 2014 untuk mengetahui Faktor-Faktor Yang Berhubungan Dengan Menarche Pada Remaja Putri Di SMP Negeri 3 Kota Jambi Tahun 2014. Populasi dalam penelitian dengan jumlah 170 siswi. Sampel dalam penelitian ini dengan jumlah 119 orang. Pengambilan sampel dilakukan dengan cara Stratified Random Sampling. Penelitian telah dilakukan di SMP Negeri 3 Kota Jambi yang pada pada tanggal 13-15 September tahun 2014. Hasil penelitian bahwa dari $62(52,1)$ remaja putri yang mengalami Menarche tidak normal mengalami aspek psikologis yang negatif yaitu sebanyak 53 $(85,5 \%)$, Hasil penelitian ini dengan nilai $p$-value adalah $0,003<0,05$ dari $62(52,1)$ remaja putri yang mengalami Menarche tidak normal dengan lingkungan sosial yang baik yaitu sebanyak $45(51,7 \%)$, hasil penelitian ini dengan nilai $p$-value adalah 0,001 $<0,05$ Simpulan penelitian ada hubungan yang bermakna antara Menarche dengan aspek psikologis dengan nilai $p$-value 0,003, kemudian Menarche dengan lingkungan sosial dengan nilai $p$-value 0,001 , serta Menarche dengan BMI dengan $p$-value 0,005 .

Menurut asumsi peneliti anak dan lingkungan merupakan dua hal yang tidak dapat dipisahkan baik itu lingkungan sekolah maupun keluarga. Anak pada usia sekolah cenderung lebih sering berinteraksi dengan lingkungan sekitar rumah, dalam rumah maupun sekolah, dalam keluarga yang kurang harmonis dapat menyebabkan terjadinya Menarche dini dan beberapan aspek struktur dan fungsi keluarga juga berpengaruh terhadap kejadian Manarche dini seperti : ketidak hadiran orang tua saat masih kecil dan kekerasan seksual.

Kesimpulan yang dapat diambil adalah bahwa lingkungan sosial mempunyai peran penting dalam terjadinya Menarche dini. Apabila seorang anak mempunyai lingkungan sosial yang kurang baik dalam kehidupan sehari-hari, dimana anak sering main sendirian, tidak mau cerita kejadian diluar rumah, orang tua sering tidak dirumah dan anak selalu sendirian dapat menyebabkan Menarche dini. Keharmonisan dalam keluarga sering main bersama, bercerita, liburan bersama dan orang tua selalu mendampingi anak bermain dan bercerita dengan ini anak akan Menarche sesuai dengan usua normal.

Hasil penelitian yang dilakukan pada 45 responden dimana media massa dikategorikan menjadi dua yaitu kurang baik dan baik. Kejadian Menarchedini dikatagorikan menjadi dua yaitu normal dan tidak normal , dapat dilihat pada Tabel 2 di bawah ini.

Tabel 2. Distribusi Responden Menurut Media Massa Terhadap Kejadian Menarchedini pada Siswi Kelas V dan VI di SDN 205 Kota Baru Kota Jambi Tahun 2018

\begin{tabular}{|c|c|c|c|c|c|c|c|}
\hline \multirow{3}{*}{ Media Massa } & \multicolumn{4}{|c|}{ UsiaMenarche } & \multicolumn{2}{|c|}{ Jumlah } & \multirow{3}{*}{$\mathrm{p}$-value } \\
\hline & \multicolumn{2}{|c|}{ Tidak Normal } & \multicolumn{2}{|c|}{ Normal } & & & \\
\hline & $\mathrm{N}$ & $\%$ & $\mathrm{n}$ & $\%$ & $\mathrm{n}$ & $\%$ & \\
\hline Kurang Baik & 1 & 6,3 & 15 & 93,7 & 16 & 100 & 0,002 \\
\hline Baik & 15 & 51,7 & 14 & 48,3 & 29 & 100 & \\
\hline Jumlah & 16 & 35,6 & 29 & 64,4 & 45 & 100 & \\
\hline
\end{tabular}

Hasil analisis hubungan antara media massa terhadap Usia Menarche dari 16 responden yang media massa kurang baik ada sebanyak 1 orang (6,3\%) yang usia Menarche tidak normal atau Menarche dini dan 15 orang (93,7\%) usia Menarche normal. Dari 29 responden yang media massa baik ada sebanyak 15 orang $(51,7 \%)$ yangusia Menarche tidak normal atau Menarche dini dan 14 orang (48,3\%) usia Menarche normal. Dari hasil Uji statistik di peroleh $\rho$ value $=0,000$, maka dapat disimpulkan bahwa secara statistik pada alpa $5 \%$ ada hubungan yang signifikan anatara media massa terhadap Menarchedini pada anak sekolah siswi kelas V dan VI di SDN 205 Kota Baru Kota Jambi Tahun 2017. Dari analisis di dapat OR 0,062 artinya responden yang media massa kurang baik mempunyai faktor penceggah (preventif)0,062kali usia Menarche tidak normal atau Menarche dini.
Hasil analisis hubungan antara media massa dengan kejadian Menarche dini pada anak sekolah siswi kelas V dan VI SDN205Kota Jambi Tahun 2018 diperoleh bahwa bahwa dari 16 responden yang katagorimedia massa kurang baik dan mengalami kejadian Menarche dini sebanyak 1 responden (6,3\%) dan yang tidak mengalami kejadian Menarche dini sebanyak 15responden (93,8\%). Sedangkan dari 29 responden yang katagori media massa baikdan mengalami kejadian Menarche dinisebanyak 15 responden $(51,7 \%)$ dan yang tidak mengalami kejadian Menarche dinisebanyak 14 responden (48,3\%).

Hasil uji statistik Chi-Square didapat nilai $p$ value 0,002 berarti $<\alpha(0,05)$. Hal ini menunjukkan bahwa ada hubungan yang signifikan antara media massa dengan kejadian Menarche dinidi SDN205Kota Jambi Tahun 2018. 
Dari analisis di peroleh pula nilai OR 0,06 artinya responden yang kurang baik media massa mempunyai peluang 0,06 kali untuk mengalami kejadian Menarche dinidibanding responden yang media massa baik.

Faktor penyebab Menarche dini juga datang dari rangsangan audio visual, baik berasal dari percakapan maupun tontonan dari film-film atau internet berlabel dewasa, vulgar atau mengumbar seksualitas. Rangsangan dari telinga dan mata tersebut kemudian merangsang sistem reproduksi dan genital untuk lebih cepat matang (Proverawati \& Misaroh, 2009).

Rangsangan-rangsangan yang kuat dari luar, misalnya berupa film-flim seks (blue flims), buku-buku bacaan dan majalah-majalah bergambar seks, godaan dan rangsangan dari kaum pria, pengamatan secara langsung terhadap perbuatan seksual atau coitus masuk ke pusat pancaindera diteruskan melalui striaeterminalis menuju pusat yang disebut pubertas inhibitor. Rangsangan yang terus menerus, kemudian menuju hipotalamus dan selanjutnya menuju hipofise parsanterior, melalui sistem portal. Hipofise anterior mengeluarkan hormon yang merangsang kelenjar untuk mengeluarkan hormon spesifik. Kelenjar indung telur memproduksi hormon estrogen dan progesteron. Hormon spesifik yang dikeluarkan kelenjar indung telur memberikan umpan balik ke pusat pancaindera dan otak serta kelenjar induk hipotalamus dan hipofise, sehingga mengeluarkan hormon berfluktuasi. Dengan dikeluarkannya hormon tersebut mempengaruhi kematangan organ-organ reproduksi (Kartono, 1992).

Penelitian ini sesuai dengan Penelitian Resminawaty dan Triratnawati (2006), mengungkapkanbahwa sumber informasi baik media elektronik maupun media cetakseperti internet, majalah, televisi, surat kabar, radio, buku, dan film akanmempengaruhi waktu terjadinya Menarche.

Hasil penelitian ini sejalan dengan penelitian Dewi (2008) yang menyatakan bahwa ada hubungan antara dampak penggunaan media massa dengan usia Menarchedilihat dari hasil uji Chi-Square didapatkan p. value $0.000<a 0,05$. Sementaradari hasil penelitian ini diketahui bahwa usia Menarcheresponden yang menggunakan media massayang buruk lebih cepat dari pada yang baik yaitu $61,5 \%$.Semakin buruk penggunaan media massa maka akan meningkat Menarche dini yang terjadi pada anak usia $<10$ tahun.

Penelitian Malani S, 2013 Analisis Faktor Hubungan Usia Menarche Dini Penelitian ini bertujuan untuk mengkaji faktor dominan yang berhubungan pada kejadian usia Menarchedini dengan menggunakan metode analisis faktor. Rancangan penelitian Cross Sectional. Total sampel 83 siswi yang sudah mengalami Menarche (menstruasi pertama). Data genetik, konsumsi makanan, hormon, sosial ekonomi, keterpaparan media massa orang dewasa (pornografi) perilaku seksual dan gaya hidup diperoleh dari kuesioner dan keadaan status gizi diperoleh dari pengukuran anthropometri. Data dianalisis menggunakan metode analisis faktor. Prevalensi Menarche dini sebesar 67,4\%. Hasil uji penelitian menunjukkan persentase keragaman faktor konsumsi makronutrien sebesar $33,20 \%$, faktor gaya hidup sebesar $18,66 \%$, dan faktor penghasilan orang tua dan olahraga sebesar $14,40 \%$.
Maka untuk meningkatan penggunaan media massa menjadi lebih baik, dalam arti tidak menyalahgunakan media massa misalnya menggunakan fasilitas internet untuk kepentingan sekolah seperti mencari tugas-tugas sekolah, maka perlu diberikan pendidikan tentang penggunaanmedia massa yang baik untuk para siswi, misalnya dengan tidak membuka situs porno di internet, tidak membaca majalah dewasa, tidak menonton tayangan dewasa, hal ini dapat dilakukan melalui penyuluhan baik dari leaflet, poster atau dari media elektronik lainnya. Sehingga para remaja dapat memilih media massa yang cocok untuk pengembangan diri

\section{SIMPULAN}

Hasil penelitian dan analisa hubungan yang telah dilakukan pada 45 responden dengan menggunakan uji statistik Chi- Squaremaka dapat dibuat kesimpulan yang merupakan jawaban atas pertanyaan dan tujuan penelitian yaitu:

1. Ada hubungan lingkungan sosia Isecara parsial dengan kejadian Menarche dini pada anak sekolah siswi kelas V dan VI SDN 205 Kecamatan Kota Baru Kota JambiTahun 2018 ( $p$ value 0,000 )

2. Ada hubungan media massa secara parsial dengan kejadian Menarche dini pada anak sekolah siswi kelas V dan VI SDN 205 Kecamatan Kota Baru Kota JambiTahun 2018 ( $p$ value 0,002 )

\section{DAFTAR PUSTAKA}

Ali, M dan Asrori. 2004. Sosial Ekonomi. Diakses pada tanggal 16 Maret 2017 jam 09.50 WIB.

Andira, D. 2010. Seluk-Beluk Kesehatan Reproduksi Wanita. A+Plus Books. Jogjakarta.

Arikunto, Suharsimi.2014."Penelitian Tindakan Kelas". Jakarta:PT Bumi Aksara.

Bambang. 2004. Faktor-Faktor Yang Berhubungan Dengan Usia Menarche Remaja Putri (9 - 15 Tahun) Sekolah Lanjutan Tingkat Pertama di Jakarta Timur.

Bobak, M dan Irene et., al. 2004. Keperawatan Maternitas. Edisi 4. EGC. Jakarta.

Cunningham, Gary F. et al, 2005. Obstetri Williams. Edisi 21. Vol. 1. EGC. Jakarta.

Godam. 2008. Defenisi status sosial ekonomi. EGC. Jakarta.

Hidayat, A. Aziz Alimul. 2008. Metode Penelitian Keperawatan dan Teknik Analisis Data. Salemba Medika Jakarta.

Kartono, 1992. Psikologi Wanita. Mengenal Gadis Remaja dan Wanita Dewasa. Mandar Maju. Bandung.

Melani, 2013. Analisis Faktor Hubungan Usia Menarche Dini Kota Jambi.

Notoatmodjo, S. 2007. IImu Kesehatan Masyarakat. Rineka Cipta. Jakarta.

Nugroho, T.dkk . 2014. Masalah Kesehatan Reproduksi Wanita. Nuha Medika. Yogyakarta

Prasetyawati, dan Arsita Eka. 2012. Kesehatan Ibu dan Anak (KIA) dalam Millenium Development Goals (MDG'S). Yogyakarta : Nuha Medika 
Proverawati A, dan Misaroh S, 2009. Menarche Menstruasi Pertama Penuh Makna. Nuha Medika. Yogyakarta.

Senjaya, S, 2010. Media Massa Media Pendidikan. EGC : Jakarta

Soetjiningsih. 2012. Tumbuh Kembang Anak. Penerbit Buku Kedokteran EGC. Jakarta 